This is a self-archived version of an original article. This version may differ from the original in pagination and typographic details.

Author(s): Lämsä, Anna-Maija; Auvinen, Tommi; Heikkinen, Suvi; Sintonen, Teppo

Title: Narrativity and its application in business ethics research

Year: 2018

Version: Accepted version (Final draft)

Copyright: @ Emerald Publishing Limited 2018

Rights: In Copyright

Rights url: http://rightsstatements.org/page//nC/1.0/?language=en

Please cite the original version:

Lämsä, A.-M., Auvinen, T., Heikkinen, S., \& Sintonen, T. (2018). Narrativity and its application in business ethics research. Baltic Journal of Management, 13(2), 279-296.

https://doi.org/10.1108/BJM-06-2017-0196 


\title{
Narrativity and its application in business ethics research
}

\begin{abstract}
Purpose - This article aims to develop a narrative framework for doing empirical research into business ethics and shows, through two examples, how the framework can be applied in practice in this context. The focus is on interview-based research.
\end{abstract}

Design/methodology/approach - A theoretical research based on literature review was conducted. Findings - In the developed narrative framework, two main kinds of analysis are distinguished: an analysis of the narrative and a narrative analysis. An analysis of the narrative is a matter of classifying and producing taxonomies out of the data. The purpose of a narrative analysis is to construct a story or stories based on the data. Narrative analysis differs from the analysis of narratives in that the story does not exist prior to the analysis, but is created during the analysis.

Research implications - The proposed narrative framework helps those doing empirical research into business ethics avoid simplistic 'black and white' interpretations of their material, and helps them to show that ethical realities in the business world are often complex, various and multiple.

Practical implications - The paper offers a methodological framework for those doing qualitative research into business ethics which will increase the quality and rigor of their studies.

Originality/value - A value of the narrative approach is that the stories offer researchers an entry point to understanding the complexity of ethics and how people make sense of this complexity. The paper shows in detail how the methods presented can be used in practice in empirical research.

Keywords Narrativity, Business ethics, Methodology, Method, Qualitative research Paper type General review 


\section{Narrativity and its application in business ethics research}

\section{Introduction}

This article makes two contributions to the discussion of empirical research on business ethics. Firstly, according to Cassell and Symon (2015), many qualitative methodologies are not wellknown to researchers in the field of organizations and management in the Baltic region despite the fact that they can offer researchers important and unique perspectives. Therefore in this article we introduce a methodological framework for doing qualitative, specifically narrative research for organization and management researchers in the field of business ethics. Although organization and management researchers are increasingly interested in business ethics as a research topic, metareviews conducted in the field (e.g. O'Fallon and Butterfield, 2005; Craft, 2013; Lehnert et al., 2015) reveal that the number of qualitative studies is very limited compared to those of quantitative studies. In their extensive review covering studies written between 1996 and 2003 in top business journals, O'Fallon and Butterfield (2005) found that only a few studies on ethical decision-making - a key area in empirical research on business ethics - used other than quantitative approaches. A similar finding was reported by Craft (2013), whose review covers the years 2004-2011. Finally, a more recent review conducted by Lehnert et al. (2015) shows that only two of the 182 studies analyzed involved qualitative analysis. However, because business ethics is difficult to measure (Campbell and Cowton, 2015), qualitative studies are important. They enable rich descriptions of and diverse viewpoints to ethics in organizational life (Lehnert et al., 2016). Increasing overall understanding of the meaning, characteristics and contextual nature of ethics in business is possible through qualititative approaches (Campbell and Cowton, 2015).

Various approaches are possible in qualitative research, such as narrative, phenomenology, ethnography, grounded theory and case study, and the approaches are not mutually exclusive (see e.g. Erikson and Kovalainen, 2008; Bryman and Bell, 2015). The framework presented in this paper draws upon Alasdair MacIntyre's (1996) widely recognized philosophy of ethics and morality. MacIntyre argues that people's understanding, construction and interpretation of ethics and morality are based on narratives. According to him, narrative is the primary form by which human experience is made meaningful. In line with MacIntyre, who connects historically and socially constructed narrative to the creation of morality and ethics, it is assumed here that narrativity is a base for all characterization of humans' ethical actions, and thus business ethics is created through 
people's narrative practices (Phillips, 1991). MacIntyre (1996, p.212) says that "we all live out narratives in our lives and because we understand our own lives in terms of the narratives that we live out the form of narrative is appropriate for understanding the actions of others". Although a link between narrative and ethics has been discussed to some extent in business ethics research, studies have mostly paid attention to one specific content-based theme, for example, the environment (Dawson, 2005), the dignity of work (Stephens and Kanov, 2017), and managers' ethical agency (Hiekkataipale and Lämsä, 2017). Consequently, the research field is fragmented and methodological frameworks are scarce.

Secondly, the article contributes to empirical research on business ethics by presenting two examples of studies (Auvinen et al., 2013; Heikkinen et al., 2014). The examples highlight two types of narrative study on business ethics: the analysis of narratives, and narrative analysis (Polkinghorne, 1988). We will focus on interview-based research since it is a common approach in current empirical qualitative research (Flick, 2007; Eriksson and Kovalainen, 2008). In particular, data creation and the analysis process are described and discussed in detail. In describing and discussing the examples we are meeting a general challenge to empirical studies in the social sciences, that is, that they are relatively silent about how qualitative data are produced and analyzed in practice (Maanen, 2010). Campbell and Cowton (2015) stress that one challenge in qualitative research on business ethics is to ensure that data collection and analysis are undertaken in strict accordance with the selected research tradition.

In line with Campbell and Cowton (2015), we argue that despite the dominance of quantitative approaches in empirical research, many issues in business ethics are essentially qualitative. Campbell and Cowton criticize contemporary empirical research on business ethics by saying that core questions in ethics such as, for example, questions of equality, fairness and right, are qualitative by nature, but researchers commonly believe that it is possible to describe them with the help of quantitative variables. This results in very limited reflection and understanding of the research phenomenon. Empirical research on business ethics needs to aim to understand how ethics and morality are experienced, enacted and constructed by people in organizational life (Phillips, 1991; Humpreys and Brown, 2008; Zydziunaite et al., 2015). Qualitative research, such as narrative investigation in this paper, can offer a fruitful alternative for achieving this aim (Jackall, 1988; Dawson, 2005; Thiel et al., 2012; Stephens and Kanov, 2017). 
Although qualitative approaches are under utilized in empirical studies on business ethics, they are useful when the research phenomenon is complex (Treviño et al., 2003; Clegg et al., 2007; Jørgensen and Boje, 2010; Campbell and Cowton, 2015). An advantage of the narrative approach is that the stories offer researchers an entry point to understanding the complexity of ethics and morality and how people make sense of this complexity (Jackall, 1988; Czarniawska, 2004; Gabriel and Griffiths, 2004; Langley et al., 2013). Narratives are seen as an important way of gaining this knowledge because narratives convey the meanings of experiences, and by studying narratives the moral salience of experiences can be understood and tackled (Jackall, 1988). Studying narratives is relevant, since narratives give meaning to events and to people's ethical character, action, and reasoning in practice (Gergen and Gergen, 1998; Gabriel and Griffiths, 2004; Stephens and Kanov, 2017). Since business people are not often willing to discuss ethics or moral rules-in-use in a direct way (Jackall, 1988; Campbell and Cowton, 2015), one strength of the narrative approach is that stories can offer an appropriate resource for the researcher to reach those sensitive phenomena (McNeil and Pedigo, 2001; Hiekkataipale and Lämsä, 2017).

Moreover, storytelling is an appropriate means to overcome the limitations of time and space by enabling people to transfer their experiences from one time and place to another, and even to create imaginary storylines in which they deal with ethically troubled issues (Ricoeur, 1984; Lämsä and Sintonen, 2006). Instead of providing only a cross-sectional view, application of the narrative framework can reveal the dynamics of social and human processes and offer an opportunity to capture a historical and temporal perspective on the topic under investigation (Conger, 1998; MacIntyre, 1996; Langley 2007). Narratives have power to make visible the processuality - the movement, activity, events, change and temporal evolution - of a research phenonomen (Langley, 2007), thus contributing to describing the development as well as the rich, dynamic and multifaceted nature of the phenomenon (Rantakari and Vaara, 2017).

In particular, the sequential order in narratives can reveal how the people who are being studied make sense of events in relation to other events over time and in particular contexts (Ricoeur, 1984; Gergen and Gergen, 1988; Gergen et al., 2004; Sonenshein, 2010; Stevenson, 2016). Through narratives, it is possible to explore how ideas about morality and ethics in business remain the same or change, patterned by the period of time and context (Sonenshein, 2010). It is also possible to detect the exercise of power, which always involves moral responsibility (Lukes, 2005), as well as whose ideas are dominant and marginalized, even excluded, in specific time periods and contexts (Humpreys and Brown, 2008; Sintonen and Auvinen, 2009). According to Baldwin (2016), one 
strength of the application of narrative in research is that it has the potential for giving voice to those marginalized in society - and also in organizations.

Additionally, narration offers people an opportunity to recount their experiences and in this process they can reveal and clarify for themselves their values, motives and ethics. This kind of dynamics can empower people and enable them to understand themselves as active agents in the construction of business ethics (cf. Pasupathi, 2001; Clegg et al., 2007; Pirson, 2017). For example, Stephens and Kanov (2017) argue that narration is important in the context of studying working life, because it helps people better understand the dignity of work. According to Ricoeur (2017), narratives are especially important in the field of ethics because the creation of narrative coherence allows the individual to consider her/himself the worthy subject of a good life, in other words, to experience self-esteem. Ricoeur claims that the ethical aim of human life is self-esteem, and that construction of one's self-esteem is an interpretation informed not only by criteria defined by oneself but also by intersubjective criteria that one draws upon and constructs in narration.

\section{Narrative framework}

\section{Paradigmatic assumptions and the concept of narrative}

As a starting point we rely on Bryman and Bell (2015), who stress that qualitative research aims to describe and interpret the meaning, not the frequency, of certain phenomena. One form of qualitative research adopts a narrative investigation, which is in itself a broad approach (see e.g. Boje, 2001; Czarniawska, 1998; Novicevic et al., 2008; Jørgensen and Boje, 2010; Andrews et al., 2013; Rosile et al., 2013; Rantakari and Vaara, 2015; Baldwin, 2016). From the viewpoint of business ethics research it can be said that narrative approaches, despite some classic exceptions (Toffler, 1986; Jackall, 1988), have only recently started to arouse a now growing interest (e.g. Humpreys and Brown, 2008; Lawrence and Maitlis, 2012; Hiekkataipale and Lämsä, 2017; Stephens and Kanov, 2017).

Until now, the research field that combines narrativity and ethics has mostly been interested in studying links between stories and ethical and moral values (Stevenson, 2016; Pirson, 2017). This kind of research relies on positivism and stresses the possibility of objective reasoning (about positivism see e.g. Bryman and Bell, 2015). Positivist research emphasizes that ethical and moral values exist in a stable and objective form somewhere outside people's actions, waiting to be found by the researcher with the help of individuals' stories. In this paper, we draw on the seminal work of 
MacIntyre (1996), who views ethics and morality as socially and historically constructed through narration. In general, MacIntyre sees the idea of life as narrated and, instead of understanding moral valuations and their reasoning as universalizable and objective - a widely applied idea in the field of business ethics, especially in the positivist tradition - he sees morality as located and produced historically and culturally.

Any empirical study in the field of narrative and ethics is governed by specific ontological and epistemological considerations (Rosile et al., 2013), which are connected to an assumption of the nature of ethics. In line with MacIntyre's (1996) understanding of ethics that we have adopted here, the ontology of the narrative framework - ideas about the existence of and relationships between people and the world in general (Eriksson and Kovalainen, 2008) - relies on social constructionism, which holds that social entities are built up from the actions of social actors (Berger and Luckmann, 1966). According to constructionists, human environments and knowledge are created and maintained by people through cultural and social practices (Berger and Luckmann, 1966). Seen from this viewpoint, understandings of ethics are contextual and historical; changes in understandings happen but they are likely to be slow (MacIntyre, 1996). An academic study in the field of business ethics of socially and culturally constructed reality is a study of the processes which make us what we are and what we should be, and which give meaning to people's experiences and ideas (Phillips, 1991; Stevenson, 2016). The epistemological assumption which defines how knowledge of ethics and morality can be produced and argued for (Eriksson and Kovalainen, 2008) relies on interpretivism. It depends on the idea that social reality has a meaning for human beings and that therefore human action such as narration is meaningful (Bryman and Bell, 2015). The task of the researcher is to gain access to people's ethical experiences, thinking and knowledge, and to interpret their social world from their point of view.

According to MacIntyre (1996), some narratives can become the prevailing ones, constituting a broader context for people's narration and understanding of morality and life. For example, business ethics researchers have argued that utilitarianism interpreted specifically as a cost-benefit analysis is an ethical standpoint widely used as the context by business people when they construct narratives of their experiences and ideas (Kujala et al., 2011; Velasquez, 2012). MacIntyre (1996) says that an individual's narration will not be understood without understanding its context. He also holds that people need to consider and reflect on how they are speaking and writing of their ideas and experiences. This highlights the importance of the speaker's moral awareness and responsibility 
in narration, and also the understanding that we are only, and to a greater and lesser extent, coauthors of our own narrative.

Narrative has been defined in various ways. Baldwin (2016) says that a rapidly increasing interest among researchers in narratives has led to a lack of shared understanding as to what is meant by the concept. Baldwin criticizes researchers for often not making things clear when they leave the term narrative undefined or, at worst, use the term as if it were simply common sense. In this paper we adopt a commonly accepted definition, that a narrative study takes narrative to be a textual account of a sequence of events which have happened to human beings or other equivalent characters (see e.g. Polkinghorne, 1988, 1995; Bruner, 1991; Ricoeur, 1991; Gergen and Gergen, 1998; Riessman, 2008). This broad definition includes three basic elements: narration (a text in spoken, written or some kind of visual form), a continuum of events (happenings, encounters, coincidences interconnected in a temporal unity by the plot) and agents (characters who produce the action and lead events on) (Ricoeur, 1984). It is the configuration of these three elements that gives meaning to the phenomena and events recounted in a story. Narratives are sequential and meaningful, definitively human; they represent and mediate experience, reconsituting it as well as expressing it; and they show transformation or change (Squire, 2013, p.48). Additionally, narratives are socially and culturally bound, performed, constructed and interpreted differently in different contexts. They convey experience by reconstituting it, and the result is multiple forms of narratives (Bruner, 1986; Ricoeur, 1991; Riessman 2008). Creating narratives is an ongoing process which, according to Czarniawska (1998, p.15), is a "never-ending construction of meaning".

Narratives are a means of human sense-making and express humans' vivid and deep experiences of themselves and of events relevant to them. They are not simply characteristic of humans, but ultimately it is narration that makes us human (Ricoeur, 2017). Consequently, it is crucial in ethics as well as in ethical investigation. According to Ricoeur (1991), the examination of life, without which life is not worth living, consists of recounting it. As narratives convey the values, norms, intentions and motivations of people and organizations, they have an ethical loading. Narratives told and heard both create and maintain meanings, thereby influencing and constructing the scope of people's ethical and moral thinking, understanding and acting (Jackall, 1988; MacIntyre, 1996; Dawson, 2005; Lawrence and Maitlis, 2012). A narrative can be conventional, uncritical, harmful and constraining, even discriminating, but it can also be good, inspiring, insightful and empowering. 
Ricoeur's (1991) idea of three narratively-mediated relations points out how narratives are intertwined in everyday sense-making and thus usable when studying business ethics. First, people's relationship to the surrounding world is mediated by narratives. We understand the world around us, for example, the ethicality of organizations, by listening to and recalling stories. It is a matter of worldviews and ideologies (Lämsä and Sintonen, 2006). As MacIntyre (1996) puts it, our construction of the world around us occurs by listening to, recalling and constructing historically, socially and culturally situated stories about good and bad, right and wrong. The second relationship is between an individual and other individuals (Ricoeur, 1991). At this level ethical meanings are communicated (Lawrence and Maitlis, 2012) - e.g. between members of an organization - in verbal, written, face to face, or virtual forms. Thirdly, there is a narrative relation between an individual and herself/himself, which refers to an individual's self-understanding and her/his identity construction (Ricoeur, 1991). It answers in an ethical sense the questions of what kind of a person I am and what kind of a person I should be (Koning and Waistell, 2012; Ricoeur, 2017). The interwined nature of these relations means that, for example, narratives of the ethicality in play in organizations allow various ethical stances to be created and presented through various social communication procesesses.

\section{Data creation and analysis}

Narrative data can be produced in several ways (e.g. letters, diaries, interviews). Riessman (2008, p. 21) has argued that "the researcher does not find narratives but instead participates in their creation". Often, narrative research data are created by means of interviews (Flick, 2007; Riessman, 2008; Squire, 2013; Gubrium and Holstein, 2012) - our focus in this article.

An interview research setting is basically built using means and conventions similar to those used in any interactional conversation in everyday life (Ruusuvuori and Tiittula, 2014). There are many ways in which an interview is an appropriate means for creating data for a narrative study. First, the interviewer can grasp the fundamental way in which humans speak, think and communicate (Fisher 1987; Polkinghorne 1988). Secondly, an interview is interactional by its very nature - as are narratives, as discursive accounts. No narrative exists by itself, but it is a social construction, a discursive unit narrated by a human being from a certain standpoint (Hacking, 1999; Lehtonen, 2004), attached to a complex web of stories (Fisher, 1986; Boje, 2001; 2008). Depending on the target of the study and the nature of the analysis, the interviewer can vary her/his role from initiator and catalyst (e.g. intensive and open interviews) to activator and even director (e.g. structured narrative interviews) (Eriksson and Kovalainen, 2008). 
In his study on how personal narratives are produced in interview conversations, Mishler (1984) addresses the social interaction between the interviewer and interviewee (see Riessman, 2015, p.226). The primary aim of an interview is not to "emancipate" the interviewee but rather to reveal as much as the interviewee is willing to narrate of the events, experiences and relations that influence the construction of the story that is told (Riessman, 2015, p.227). However, emancipation can occur in an interview that resonates particularly well with the interactional and reflexive nature of the interviewee. The interviewer can encourage or constrain an interviewee's narration with her/his attitude. Gabriel and Griffiths (2004) consider what means a researcher can use to elicit stories in dyadic interaction; they suggest that the researcher might even switch on and off the taperecorder with a view to stimulating the interviewee. As an example of emancipation, Gabriel and Griffiths (2004) suggest that if in an anecdote the interviewee light-heartedly or humorously criticizes her/his superior, the teller can fall back on the defence, "It was only a joke/story" if the listener responds in a certain way.

Narrative data are temporal in nature (Søderberg, 2003) and one of their crucial features is that they involve emplotment. Emplotment refers to an operation in analysis by which the various heterogeneous events become integrated and organized appropriately into a solid and wellconstructed story (Ricoeur, 1984, 1991). Emplotment highlights how events relate to one another and form sequences. Furthermore, in any story there exists a tension between concordance and discordance. To form a coherent and understandable story from heterogeneous events by emplotment, the concordance of events should outweigh the discordance. (Ricoeur, 1984, 1991.)

Emplotment is crucial for any ethical analysis, because a story creates a social center (White, 1987) and purpose for the events that are related (Polkinghorne, 1995). Although narrative inquiry usually utilizes diachronic instead of synchronic data (Polkinghorne, 1995), plain temporality, i.e. a list of events in chronological order, is not sufficient for the evaluation of events in an ethical sense, because itemizing the events and organizing them into temporal order does not say anything about their moral, social and cultural meanings and mutual relations. As White (1987, p.11) has stated, narrative form, which creates a social center for a story, makes it possible to locate events in relation to each other and charge them with ethical significance. This is not to say that narrative form is the only way to access ethical elements, but it illustrates how they can become targets for examination in narrative data. 
In the practical examples in this paper, two main kinds of analysis are distinguished: an analysis of the narrative and a narrative analysis (Polkinghorne, 1995). They differ in many aspects, from the manner of reasoning to type of data. Because they form the basis for our practical examples of narrative inquiry in business ethics below, they will be explained next.

An analysis of the narrative focuses on general or common features in a corpus of stories. The data are in the form of stories, usually not a single story, and the analysis aims at finding themes, characters, sequences and other narrative elements which are common to every single story. Thus, it is a matter of classifying and producing taxonomies out of the data; the direction of the analysis is from stories to what the stories have in common, from the particular to the general. This approach may not only be concerned with identifying sets of categories; it can also seek to identify the relationships that hold between and among the established categories. Categories can be derived either from previous theory or inductively from the data. Qualitative content analysis, thematic analysis and grounded theory approach (see more e.g. Bryman and Bell, 2015; Riessman, 2008; Bryant and Charmaz, 2010) are examples of conducting an analysis of the narrative.

The purpose of a narrative analysis is to construct a story or stories based on the data (Gergen and Gergen, 1998; Polkinghorne, 1995). Narrative analysis differs from the analysis of narratives in that the story does not exist prior to the analysis, but is created during the analysis. The data for narrative analysis may consist of more or less fragmented descriptions of events and incidents which may not have a clear connection with each other, but the result of the analysis is a narrative which can be, for example, a history, life-story or any kind of episode of human conduct which has a plot. Narrative analysis is a process of configuring narrative elements into a story endowed with ideas of human purpose and disposition. In such an analysis, the researcher configures the diverse elements of a particular human action or experience into a unified whole in which each element is connected to the central purpose of the action. (Polkinghorne, 1995.)

Let us now turn our attention to two practical examples which show in detail how the methods described above can be used in practice. Both examples are based on interview data. The first example is of the analysis of narratives, and the second example is of narrative analysis.

\section{Example 1: Analysis of narratives}


The first example is a study of a leader's manipulative storytelling. Originally, the study focused on the stories that leaders told to their employees to influence them. The original research task was therefore to investigate what kind of positive stories leaders tell their employees in order to motivate, inspire and engage them; we did not take into consideration any problems or ethical aspects of the influencing. In this sense our positioning in the study (Riessman, 2015) was a traditional leadership stance (see e.g. Yukl, 2010), which does not stress ethical tensions, questionable motives or intentions in leadership goals and behavior. However, during the process of analyzing the interviews we found somehow quite accidentally that some leaders constructed themselves in the interviews as dishonest in their behavior as leader. This was not what we had expected of the stories and it aroused our interest. Therefore, after several discussions in our research group, we decided to make a study of concealed intentions and behavior in leadership from an ethical and more critical perspective, instead of using the traditional approach. Finally, we decided to focus on manipulation and to investigate whether there was any manipulative influencing in the stories. (Auvinen et al., 2013.)

It can be said that in this case, producing the interview data gave us an opportunity to take a quite new approach and go beyond our original assumptions about leadership, as well as to enrich and challenge the traditional approach in leadership research with an alternative, surprising and unexpected viewpoint. However, another issue that we felt had to be considered, discussed and decided in the research group was whether it was consistent with research ethics to take a different stance from the one originally planned. When originally introducing the topic to interviewees to get their permission for the research, we had informed them that our aim was to study any stories that leaders told their employees in order to influence them. Although our assumption then was that only positive stories would occur, the interviewees themselves decided in the interviews to tell other types of stories too. So, in response to their voluntarily telling these different kinds of stories, we as researchers decided that we could change our stance, that it was ethically acceptable.

The study applied the analysis of narratives because the data consisted of complete stories, and the analysis proceeded from stories to what features they had in common. The outcome of this research was that categories of manipulative leadership stories were formed and certain ethical frames were identified within them.

To obtain a many-sided view of the topic, the data were produced through semi-structured interviews with open-ended questions. The researcher had a list of questions on fairly specific 
themes to be covered, but the interviewee had a great deal of leeway in how to reply (Bryman and Bell, 2015). The goal was that the interview situation should resemble a smooth conversation (Squire, 2013) and the interviewee should be able to reflect on and bring out her/his experiences and their significance (Polkinghorne, 2007). At the beginning of the interview the researcher had a more directional role in the co-creation of the data, but when the interviewees started telling stories, the position of the interviewer moved more into the role of listener in the interaction.

A heterogeneous group of leaders was selected for the research by purposeful sampling (Patton, 2002), in which three criteria were used. Firstly, since the focus of interest was leaders, the interviewees had to have a leadership position in their organization. Secondly, since storytelling was also in focus, all the leaders had to be either publicly known (through the media) or recommended by their employees and colleagues as good storytellers in their official capacity as leaders. Finally, to avoid gender bias, the sample had to have both female and male participants. (Auvinen et al., 2013.) The themes of the interviews revolved around reflections on the leaders' own leadership style, the role of storytelling in their leadership work, and the stories they used to influence their subordinates. In particular, the leaders were invited to recall actual stories that they had used in their everyday leadership practices and to describe the situation in which the stories were told. (Auvinen et al., 2013.) The focus was not on long diachronic stories, such as life stories, but on the commonalities and differences in events in shorter stories.

In this example, in line with the selection criteria described above, a total of 18 participants were interviewed. However, after completing the interviews and getting to know the data set better, it was noticed that only nine participants' interviews actually included stories that could be interpreted as manipulative and coherent enough to be understood as a story in the sense defined in the framework of the study. Consequently, nine interviewees were excluded from the sample and nine were included in the final data set. These nine participants told 13 stories which were regarded as worth analyzing. (Auvinen et al., 2013.) The unit of analysis, then, was a manipulative story related to a particular situation or event in leadership, not a whole interview.

There can be various reasons why a part of the data was not appropriate in this particular study. First, not all the text in the data met the definition of a story in the narrative framework. Even if a story can be in a more or less coherent or fragmented form, it needs to deal with events and happenings which are configured into a temporal unity by means of a plot (Polkinghorne, 1995; Riessman, 2008). Second, managers might consider that manipulation is a rather sensitive topic, and 
they might therefore have been hesitant to reveal in an interview any attempts at manipulation that they have made. Some of them would obviously aim to create a more positive self-image (Polkinghorne, 2007) by talking about more neutral events than those which could be understood as manipulation within the terms of this study.

The analysis started by transcribing all of the interviews word by word. The analysis took place in four different phases. In the first phase, the researchers in the team individually read through the entire transcribed data (e.g. Flick, 2007; Eriksson and Kovalainen, 2008). As an outcome of the first phase, the data were given a preparatory order (Auvinen et al., 2013). The goal of the second phase was to identify the leadership storytelling situations which had hints of manipulation (cf. Wrong, 1999). As mentioned above, as an outcome of the second phase it was possible to detect manipulative storytelling in nine managers' interviews, resulting altogether in 13 manipulative stories. Some of the stories were relatively coherent with a chronological order of events (Søderberg, 2003), others were briefer and more fragmented (Boje, 2001).

In the third phase, a thematic analysis (Riessman, 2008) was conducted. According to Riessman (2008, p.53), all narrative inquiry is concerned with "what" is said, and in our study this meant that the 13 stories were next classified according to their meanings into thematic groups so that each group had a common, overarching meaning. Polkinghorne's (1995) idea of the identification of common themes among stories was adopted, and as a result, four categories of manipulative leadership stories were identified: humorous, pseudo-participative, seductive, and pseudoempathetic manipulation Auvinen et al., 2013). Finally, in the fourth phase an ethical analysis was carried out of each of the categories. Three ethical facets - consequences, duty and virtue ethics were used in the analysis. In other words, all 13 stories in the four categories were analyzed using each of the three facets, and as a result it was possible to identify different ethical facets in different categories. (Auvinen et al., 2013.)

In the following table, Table 1, one particular category (humorous) is presented to show the analysis process. The outcome of each phase of analysis is illustrated in the different columns (1-6).

Insert Table 1 here

Column one is the identifier of a particular story. Each story was given an illustrative title for ease of reference, for example in discussions among the members of the research group. Column two 
labels the category of manipulation. For instance, the humorous category refers to the leader's way of joking and using anecdotes in his/her narration as a core idea in the manipulation. Column three gives information about the context in which the story was told. A synopsis of the actual story, which was rather brisk and coherent, is presented in column four. It should be noted that most stories ( 9 out of 13) were coherent. The form of manipulation in column five describes the discursive practice of the leader in question: the manipulation was based on giving the follower disinformation. The ethical facet is presented in column six.

There are at least two positive outcomes of this study. First, the study made visible the ethical frames of reference that leaders can use while manipulating their followers. Although among the leaders manipulation was mainly considered to be unacceptable, there were some situations in which manipulation was deemed to be inevitable for the good of either the follower or the organization. Thus, the study showed that manipulation does not appear disconnected from moral reasoning, but relies always on some kind of morality. Second, the study showed that narrative inquiry made by means of the analysis of narratives opened up the way to uncovering and analyzing the morals, purposes and reasoning which were relevant and familiar to the actors and, consequently, despite the sensitiveness of the topic, relatively easy for them to talk about in a research interview (cf. Jackall, 1988). The actors could bring out events which had happened to them in their actual work much more easily than would have been the case using, for example, vignettes in a study.

\section{Example 2: Narrative analysis}

The second example in the present paper deals with a study which used narrative analysis. The example of narrative analysis deals with a study of spousal support for the careers of women managers (Heikkinen et al., 2014). This study focused on how the relationship between the manager and spouse was recounted by the manager to the interviewer.

The first objective was to conduct a narrative study of women managers and identify how they perceived their spouses' support during their career. The second objective was to examine what kind of gender relations the women managers created when discussing their experiences of spousal support for their career paths. This was done in order to investigate (in)equalities in the relationship between the woman manager and her spouse. (Heikkinen et al., 2014.) In this study, our original aim was to study specifically spousal support. However, after producing the interview data and 
reading the data carefully, it became clear that the women's narrations also included a lot of talk about problems and obstacles that their spouses put in the way of their career. Although it would have been possible still to focus only on support, we thought that such a study would not properly reflect the women's narration of the topic. Instead of the original idea, then, we decided to explore both spousal support and non-support. In practice, this made it necessary to write a much longer research paper than had originally been planned. Although we kept the paper as short as we could, this meant that our choice of journal was restricted and we had to choose one that accepts long texts. Even then, describing the data in a transparent way, showing the change in the spousal support or non-support in the course of the women's career, was challenging.

Thus, spousal (non-)support and gender (in)equality were analyzed against the woman's career path over time, and that was why Polkinghorne's (1995) narrative analysis approach was chosen. During the narrative analysis, different elements in the women managers' descriptions of the topic were condensed into the following types of support: harmoniously flourishing spousal support, irrelevant spousal support, quitting deficient spousal support, and inconsistent spousal support. The outcome of this research data was a collection of new narratives, called ideal narratives below, which were used as the context in the analysis of gender in(equality). (Heikkinen et al., 2014.)

The model of Gergen and Gergen (1988) was used to analyze the ethical elements of spousal support and gender (in)equality in the narratives of this study. The task was to construct narratives that displayed the linkage between the data elements as parts of an unfolding temporal development culminating in denouement. Gergen and Gergen (1988) argue that all plots can be converted into a stable, progressive or regressive linear narrative form with respect to their evaluative shifts over time, and that these forms can be considered rudimentary bases for other, more complex variations. These narrative forms are tragedy, comedy, 'happily-ever-after' and romance. Tragedy in this sense contains a regressive storyline, and would tell a story of downfall and disappointment. Comedy and 'happily-ever-after' are the reverse of tragedy, and both are dominated by a progressive storyline. The comedy narrative consists of some challenges or problems prior to a happy denouement, and in the 'happily-ever-after' narrative, progression is followed by a blissful, stable conclusion. The narrative of romance consists of many progressive-regressive phases. (Heikkinen et al., 2014.)

To produce the research material, 25 women managers were interviewed in interviews lasting from one to two hours. The interviews took place in the women's workplaces in offices reserved for the research purpose, so they were quiet places in which the interviews could be carried out without any 
disturbance. (Heikkinen et al., 2014.) This arrangement was seen as important since the researchers thought that the topic might be rather sensitive to the interviewees. In this study purposeful sampling (Patton, 2002) was used as the sampling strategy. The interviewees were selected with certain criteria in mind. First, women managers who were in mid- and late career were interviewed since it was considered that these women would have sufficient experience of life and work to be able to look back and reflect on their careers. Second, each woman needed to have or have had at least one spouse. The main idea of the interviews was to enable the managers themselves to tell about their world of work, in this case their career, and the world of family, in this case their spouse (cf. Lee et al., 2011). For this reason a thematic but rather loose semi-structured interview guide was applied that would cover the successive phases of the woman's career and family life up to the present. (Heikkinen et al., 2014.)

In the interview each interviewee established a valued end point of spousal support, made a selection of events relevant and appropriate to the stated and valued end point, and ultimately established for herself causal linkages between the issues she spoke about. This gave a vantage point from which it was possible to figure out how one person, i.e. each woman manager in this study, experiences and constructs her life and career in relation to spousal support. The research data can be characterized as diachronic in that they contained temporal information about the relationship of the events in the women's careers (Polkinghorne, 1995), and that temporal information enabled the construction of ideal narratives. The research materials cover events in the respondents' life courses over time (cf. Atkinson, 1998; Moen and Sweet, 2004). This kind of data made it possible to analyze what spousal support consisted of over the course of the women's careers and lives as well as the women's evaluation of the change in (in)equalities in the gender relations between her and her spouse during this time.

A catalytic and chronologic interviewing style was used in this study (Atkinson, 1998). This means that specific types of questions were used in order to clarify the topics over the course of the woman's career and life. Comments were made and questions asked which made the interviewee reflect, re-think, and speak more about her experiences. This way of interviewing thus helped the interviewees to remember and describe experiences they had had during their life and, specifically, during their career. Examples of the kinds of catalytic questions that were asked are: Can you say more about this issue? Can you give an example of your idea in practice? Can you explain your experience in other words? The catalytic style was experienced as fruitful by the researchers, especially when more information was needed on a specific matter or event. 
The interview protocol meant that the events and experiences of the woman's work life in relation to her family life could be captured broadly in chronological order (Lee et al., 2011). For this reason the interviews began with the early phases of the woman's career, moved on chronologically to the present and also touched upon some aspects of the future. The aim of this interview setting was to enable the woman to speak about and evaluate her life in her own words. The researchers noticed that this chronological approach to the life course was easy for the interviewees to understand and meaningful to them, and allowed them to make sense of their career in their broader life context.

In the beginning of the analysis the purpose was to identify from the word-for-word transcripts of the interviews what spousal support could mean for each of the female managers. Although this was not considered to be narrative analysis (if anything it was more like the analysis of narratives) it had to be done to distinguish between the different kinds of support. Three types of support were identified: psychosocial support, hands-on support, and career assistance (Heikkinen et al., 2014). After that, Gergen and Gergen's (1988) framework of a storyline was adopted. This framework provided a way to examine the evaluative shifts in the perceived spousal support and the related gender relations throughout the women's careers. In this phase the analysis was deepened into narrative analysis by constructing storylines of the careers (Polkinghorne, 1995). Gergen and Gergen (1988) noted that in narratives people can view and reflect on various events as moving over time through evaluative space. This means that when the woman manager expressed spousal support as a valued outcome in gender relations between the spouses, the storyline became more positive, indicating happiness and satisfaction in her life and career. On the other hand, the storyline became more negative when unhappiness, disappointment and failure were recounted. (Heikkinen et al., 2014.)

The narrative analysis was utilized holistically to gain a comprehensive understanding of the topic and capture the evolution of the phenomenon over time. The researchers examined whether there were different forms of spousal support, or a lack of it, over the course of the woman's career. Thus, the career narratives, configured from the elements of the interviews, functioned as the center around which the analysis of spousal support was conducted. To make the analysis easier, the individual stories were also condensed into three ideal narratives: narratives where the woman narrated that spousal support was present throughout her career, narratives of a lack of spousal support, and narratives which did not belong in either of these groups. (Heikkinen et al., 2014.) 
It was also noticed that the spousal support might not remain the same during the course of a career; instead, the type of support present at a certain phase of the career could disappear altogether or change into another type. Therefore any changes in spousal support were analyzed and evaluated particularly thoroughly within each storyline. Finally, after many reformulations, the storylines were divided into four groups of ideal narratives: 1) spousal support developing harmoniously in line with the career, 2) managing on one's own 3) freeing oneself from inadequate spousal support, and 4) in a state of flux (Heikkinen et al., 2014). In Table 2, one storyline, spousal support developing harmoniously in line with the career, is presented to illustrate the analysis.

Insert Table 2 here

In the first column the name of the narrative is presented. The key content of this narrative is introduced in the second column, while the third column gives the storyline of the narrative according to the theory of Gergen and Gergen (1988). Finally, the fourth column gives a short description of the spousal support, its evolution over the course of the woman's career and life and its connection to the gender relations between the spouses.

Taken together, the analysis process presented above shows one way in which a narrative analysis can be conducted in the narrative framework. Analyzing the development of spousal support helped to interpret the dynamics of (in)equalities between the female manager and her spouse during the woman's career. This contributed to understanding both the current situation and the changes in gender (in)equality between the spouses over time. Narrative analysis can also make apparent the gendered power relations in everyday practices in both organizational and family life. The risk is that if gender order is left untouched and unchallenged, it may unintentionally maintain and produce unequal power relations between spouses in the career and family context. Narrative analysis enables the outlining of (in)equality and occasions of change as well as changes in gender (in)equality between the spouses over time, showing that (in)equality is not a static but a dynamic phenomenon.

\section{Summary of the examples}

Table 3 summarizes the two examples. 
In the first example, quite short stories in coherent or fragmented forms - although most often in a relatively coherent form - were produced in the thematic interviews. The 13 stories that qualified for inclusion dealt with different events in which the managers described using manipulative storytelling in communication between themselves and their staff members. The interviewing technique was thematic interviewing, which meant rather broad themes that were not in any choronological order.

In contrast, as highlighted in Table 3, in the second example the focus was not on event-based stories, as was the case in the first example, but rather on the 25 interviewees' coherent accounts of processes over their career in the broader context of their whole lives. The interviewing technique in the second case followed a loose semi-structured pattern, with the result that the whole career and its phases as well as the relationship between the interviewee and her spouse during her managerial career were discussed in the same chronological order and with the same specific questions with each interviewee. In both examples the interview questions were open-ended, which gave the opportunity for free and varied discussions between the researcher and the interviewee.

Finally, Table 3 presents the outcomes of the example studies. In the first example the outcome was that the 13 stories told by the managers in their interviews were categorized into four themes of manipulation in leadership storytelling on the basis of their core meanings. In the second example narrative analysis resulted in four different storylines which highlight the evolution of the spousal support provided in the course of the careers of the managers who were interviewed.

\section{Discussion and conclusion}

The aim of this article was to develop a narrative framework for doing empirical research into business ethics and it has shown, through two examples, how the framework can be applied in practice in this context. Drawing upon the conceptualization of Polkinghorne (1995), the empirical examples presented here highlight two types of narrative inquiry that can be used in studying business ethics: the analysis of narratives and narrative analysis. The contribution of this paper is that it offers a methodological framework for those doing qualitative research into business ethics which will increase the quality and rigor of their studies. 
The narrative framework has interesting implications for empirical research into business ethics that need to be considered. First, this approach reveals how everyday ethical issues can be a part of a bigger whole in organizational life and society in general. It provides an understanding of the context in which ethical decision making, events and experiences emerge in the business world, and helps researchers to understand the actors in their own environment. This was the case especially in the example of narrative analysis, in which the storylines formed the narrative center for the evaluation of single elements talked about in the interviews. By configuring the narratives it was possible to investigate gender (in)equalities during the woman managers' careers. The awareness that ethics is contextual emerges in the example of analysis of narratives. A plain list of the events in leaders' stories about their manipulative influence would not be adequate for an analysis of ethics, because it does not tell anything about the meaning and purpose of the events and what they have in common.

The second implication is that the narrative framework provides culturally, socially and historically situated knowledge (MacIntyre, 1996). This enables us to access phenomena related to business ethics sensitively and discreetly. Topics such as manipulation in leadership (the first example used in this paper) or gender (in)equality (the second example in this paper), are ethically sensitive issues. However, finding out what kind of stories people tell concerning their experiences of such topics and their attitudes to them without demanding that they should evaluate their own ethicality or the ethicality of a family member or close colleague seems to work well and feel comfortable through narrative interviewing. Additionally, the framework makes it possible to show that ethical issues can vary at different times, and in different places and social contexts, and it can therefore reveal many types of realities and 'everyday truths' which may occur in different contexts.

There are also limitations which should be taken into consideration when the narrative framework is used. Stories told in interviews can be seductive (Gabriel, 2008), and the interviewer may interpret a story as a template of her/his own experiences. If this happens, the critical ability of the interviewer declines. Another limitation is that only one specific perspective is adopted in interviewing; this tends to reduce the complexity of the narration, resulting in an emphasis on only one point of view of the topic under investigation (Cohen and Tyson, 2002). Finally, Gabriel (2008) warns scholars that applying a narrative approach can make them feel too comfortable with stories: stories can also be vehicles of dissimulation and lying. 
Because narrative research is a broad field, a study needs to be carried out that gives an overview of narrative research on business ethics to date and clarifies the links between the various narrative approaches and their ethics. This could be done using, for example, the model of Rosile et al. (2013), which offers an overview of the various approaches and explains their ontological and epistemological assumptions. However, the model lacks an ethical perspective which, we suggest, could be of great value. Another interesting topic for future research would be an empirical study in a specific societal and/or organizational context on how the narration of business ethics is constructed in time. This study could show empirically how changing or unchanging the constructions of ethics in business are. The narrative framework would provide a theoretical lens for such a study.

Finally, we conclude that the proposed narrative framework helps those doing empirical research into business ethics avoid simplistic 'black and white' interpretations of their material, and helps them to show that ethical realities in the business world are often complex, various and multiple.

\section{Acknowledgments}

This research was supported by the program Equality in Society (WeAll project, 292883), strategic research funding of the Academy of Finland (weallfinland.fi). We gratefully acknowledge this support.

\section{References}

Andrews, M., Squire, C. and Tamboukou, M. (Eds.) (2013), Doing narrative research, $2^{\text {nd }}$ ed. London, Sage.

Atkinson, R. (1998), The life story interview, Thousand Oaks, Sage.

Auvinen, T., Lämsä, A-M., Sintonen, T. and Takala, T. (2013), ”Leadership Manipulation and Ethics in Storytelling”, Journal of Business Ethics, Vol. 116 No. 2, pp. 415-431.

Baldwin, (2016), "Introduction to special issue: narrative across disciplines", Narrative Works: Issues, Investigations, \& Interventions, Vol. 6 No. 1, pp. 1-14.

Berger, P.L. and Luckmann, T. (1966), The social construction of reality: a treatise in the sociology of knowledge. Garden City, NY: Anchor Books.

Boje, D. (2001), Narrative methods for organizational and communication research, London, Sage. Boje, D. (2008), Storytelling Organizations, London, Sage. 
Bruner, J. (1991), “The narrative construction of reality”, Critical Inquiry, Vol. 18, pp. 1-21.

Bryant, A. and Charmaz, K. (Eds.) (2010), The SAGE handbook of grounded theory, London, Sage. Bryman, A. and Bell, E. (2015), Business research methods, $4^{\text {th }}$ ed., Oxford, Oxford University Press.

Campbell, D. and Cowton, C. (2015), "Method issues in business ethics research: finding credible answers to questions that matter", Business Ethics: A European Review, Vol. 24:S1, pp. S3S10.

Cassell, C. and Symon, G. (2015), "Qualitative research: opportunities for researchers in the Baltic region", Baltic Journal of Management, Vol. 10 No. 2, https://doi.org/10.1108/BJM-02-2015-0033.

Clegg, S., Kornberger, M. and Rhodes, C. (2007), "Business ethics as practice", British Journal of Management, Vol 18, pp. 107-122.

Cohen, C. and Tyson, D. (2002), "Teaching blind men to see the elephant: using narrative in assessment and change management", Knowledge Directions, Vol. 3 No. 2, pp. 66-75.

Conger, J.A. (1998), "Qualitative research as the cornerstone methodology for understanding leadership", Leadership Quarterly, Vol. 9 No. 1, pp. 107-121.

Craft, J.L. (2013), “A review of the empirical ethical decision-making literature: 2004-2011", Journal of Business Ethics, Vol. 117 No. 2, pp. 221-259.

Czarniawska, B. (1998), A narrative approach to organization studies, London, Sage.

Czarniawska, B. (2004), Narrative in social science research, London, Sage.

Dawson, D. (2005), “Applying stories of the environment to business: what business people can learn from the virtues in environmental narratives", Journal of Business Ethics, Vol. 58, pp. $37-49$.

Eriksson, P. and Kovalainen, A. (2008), Qualitative methods in business research, London, Sage.

Fisher, W.R. (1987), Human communication as a narration: toward a philosophy of reason, value, and action, South Carolina, Columbia, University of South Carolina Press.

Flick, U. (2007), Designing qualitative research, London, Sage.

Gabriel, Y. (2008), "Seduced by the text: the desire to be deceived in story, memoir and drama", Tamara Journal, Vol 7 No. 2, pp. 154-167.

Gabriel, Y. and Griffiths, D.S. (2004), "Stories in organizational research", in Cassell, C. and Symon, G. (Eds), Essential guide to qualitative methods in organizational research, London, Sage, pp. 114-126.

Gergen, K.J., and Gergen, M.M. (1988), "Narrative and the self as relationship", in Berkowitz, L. (Ed.), Advances in experimental social psychology, San Diego, Academic Press, pp. 17-56. 
Gergen, K.J., Gergen, M.M. and Barrett, F.J. (2004), "Dialogue: life and death of the organization”, Grant, D., Hardy, C., Oswick, C. and Putnam, L. (Eds.), The Sage handbook of organizational discourse, London, Sage, pp. 39-59.

Gubrium, J.F. and Holstein, J.A. (2012), "Narrative practice and the transformation of interview subjectivity", in Gubrium, J.F., Holstein, J.A. Marvasti, A.B. and McKinney, K.D. (Eds.), The SAGE handbook of interview research: the complexity of the craft, Thousand Oaks, Sage, pp. 27-44.

Hacking, I. (1999), The social construction of what?, Cambridge, Massachusetts, Harvard University Press.

Heikkinen, S., Lämsä, A-M. and Hiillos, M. (2014), "Narratives by women managers about spousal support for their careers", Scandinavian Journal of Management, Vol. 30 No. 1, 27-39.

Hiekkataipale, M. and Lämsä, A-M. (2017), ’(A)moral agents in organisations? The significance of ethical organisational culture for middle managers' exercise of moral agency in ethical problems", Journal of Business Ethics. DOI:10.1007/s10551-017-3511-9. (In press).

Humphreys, M. and Brown, A. D. (2008), An analysis of corporate social responsibility at credit line: a narrative approach, Journal of Business Ethics, Vol. 80 No. 3, pp. 403-418.

Jackall, R. (1988), Moral mazes, Oxford, Oxford University Press.

Jørgensen, K.M. and Boje, D.M. (2010), "Resituating narrative and story in business ethics", Business Ethics: A European Review, Vol. 19 No. 3, pp. 253-264.

Koning, J. and Waistell, J. (2012), "Identity talk of aspirational ethical leaders”, Journal of Business Ethics, Vol. 107 No. 1, pp. 65-77.

Kujala, J., Lämsä, A-M. and Penttilä, K. (2011), "Managers' moral decision-making patterns over time: a multidimensional approach". Journal of Business Ethics, Vol. 100 No. 2, pp. 191207.

Lämsä, A-M. and Sintonen, T. (2006), “A narrative approach for organizational learning in a diverse organization”, Journal of Workplace Learning, Vol. 18 No. 2, pp. 106-120.

Langley, A. (2007), "Process thinking in strategic organization", Strategic Organization, Vol. 5, No 3, pp. 271-282.

Langley, A., Smallman, C., Tsoukas, H. and Van de Ven, A.H. (2013), "Process studies of change in organization and management: unveiling temporality, activity and flow", Academy of Management Journal, Vol. 56, No. 1, pp. 1-13.

Lawrence, T.B. and Maitlis, S. (2012), "Care and possibility: enacting an ethic of care through narratives practice", Academy of Management Review, Vol. 37 No. 4, pp. 641-663. 
Lee, M.D., Kossek, E.E., Hall, D.T. and Litrico, J.B. (2011), "Entangled strands: A process perspective on the evolution of careers in the context of personal, family, work, and community life", Human Relations, Vol. 64 No. 12, pp. 1531-1553.

Lehnert, K, Craft, J, Singh, N. and Park, Y-H. (2016), “The human experience of ethics: a review of a decade of qualitative ethical decision-making research", Business Ethics: A European Review, Vol. 25 No. 4, 498-537.

Lehnert, K, Park, Y-H. and Singh, N. (2015), "Research note and review of the empirical ethical decision-making literature", Journal of Business Ethics, Vol. 129 No. 1, 195-219.

Lehtonen, M. (2004), Merkitysten maailma. Kulttuurisen tekstintutkimuksen lähtökohtia, Tampere, Vastapaino.

Lukes, S. (2005), Power, a radical view, $2^{\text {nd }}$ ed., London, Palgrave.

Maanen, J. van (1979), "Recaliming qualitative methods for organizational research: a preface", Administrative Science Quarterly, Vol. 24, pp. 520-526.

Maanen, J. van (2010), “A song for my supper: more tales of the field", Organizational Research Methods, Vol. 13 No. 2, pp. 240-55.

MacIntyre, A. (1996), After virtue: a study in moral theory, $7^{\text {th }}$ ed., London, Duckworth.

McNeill, M. and Pedigo, K. (2001), "Western Australian managers tell their stories: ethical challenges in international business operations", Journal of Business Ethics, Vol. 30 No. 4, pp. 305-317.

Moen, P. and Sweet, S. (2004), "From 'work-family' to 'flexible careers': a life course reframing", Community, Work \& Family, Vol. 7 No. 2, pp. 209-226.

Novicevic, M.M., Harvey, M.G., Buckley, M.R. \& Adams, G.L. (2008), "Historicism in narrative reviews of strategic management research", Journal of Management History, Vol. 14 No.4, pp. 334-347.

O'Fallon, M.J. \& Butterfield, K.D. (2005), “A review of the empirical ethical decision-making literature: 1996-2003”, Journal of Business Ethics, Vol. 59 No. 4, pp. 375-413.

Pasupathi, M. (2001), “The social construction of the personal past and its implications for adult development", Psychological Bulletin, Vol. 127 No. 5, pp. 651-672

Patton, M.Q. (2002), Qualitative research \& evaluation methods, Thousand Oaks, Sage.

Phillips, N. (1991), "The sociology of knowledge: Toward an existential view of business ethics", Journal of Business Ethics, Vol. 10 No. 10, pp. 787-795.

Pirson, M. (2017), "Better stories needed: how meaningful narratives can transform the world", Humanistic Management Journal, Vol 2 No. 1, pp. 1-6. 
Polkinghorne, D. (1988), Narrative knowing and the human sciences, Albany, State University of New York Press.

Polkinghorne, D.E. (1995), "Narrative configuration in qualitative analysis", in Hatch, J.A. and Wisniewski, R. (Eds.), Life history and narrative, London, Falmer, pp. 5-23.

Polkinghorne, D.E. (2007), "Validity issues in narrative research", Qualitative Inquiry, Vol. 13 No. 4, pp. 471-486.

Rantakari, A. and Vaara, E. (2017), "Narratives and processuality”, in Langley, A. and Tsoukas, H. (Eds.), Sage handbook of process organization studies, London, Sage, pp. 271-285.

Ricoeur, P. (1984), Time and narrative, Volume 1, Chicago, The University of Chicago Press.

Ricoeur, P. (1991), "Life quest of narrative", in Wood, D. (Ed.), On Paul Ricoeur. Narrative and interpretation, London, Routledge, pp. 20-33.

Ricoeur, P. (2017), "Paul Ricoeur (1913-2005)”, Internet encyclopedia of philosophy. A PeerReviewed Academic Resource. Available http://www.iep.utm.edu/ricoeur/. Accessed 25 August, 2017.

Riessman, C.K. (2008), Narrative methods for the human sciences, London, Sage.

Riessman, C.K. (2015), "Entering the hall of mirrors. Reflexivity and narrative research", in De Fina, A. and Georgakopoulou, A. (Eds.), The handbook of narrative analysis. Wiley \& Sons. pp. 219-238. Available: Wiley online library http://onlinelibrary.wiley.com/book/10.1002/9781118458204. Accessed in 29 August, 2017.

Rosile, G. A., Boje, D. M., Carlon, D. M., Downs, A. and Saylors, R. (2013), "Storytelling diamond: an antenarrative integration of the six facets of storytelling in organization research design", Organizational Research Methods, Vol. 16 No. 4, pp. 557-580.

Ruusuvuori, J. and Tiittula, L. (2014), "Tutkimushaastattelu ja vuorovaikutus”, in Ruusuvuori, J. and Tiittula, L. (Eds.), Haastattelu, tutkimus, tilanteet ja vuorovaikutus. Vastapaino, Tampere, pp. 22-56.

Sintonen, T. and Auvinen, T. (2009), "Who is leading, leader or story? The power of stories to lead”, Tamara Journal for Critical Organization Inquiry, Vol. 8, No. 8, pp. 95-109.

Søderberg, A. (2003), "Sensegiving and sensemaking in an integration process: A narrative approach to the study of an international acquisition", in Czarniawska, B. and Gagliardi, P. (Eds.), Narratives we organize by. Philadelphia, John Benjamins, 3-35.

Sonenshein, S. (2010), "We're changing - or are we? Untangling the role of progressive, regressive, and stability narratives during strategic change implementation", Academy of Management Journal, Vol. 53, No. 3, pp. 477-512. 
Squire, C. (2013), "Experience-centred and culturally-oriented approaches to narrative", in Andrews, M., Squire, C. and Tamboukou, M. (Eds.), Doing narrative research, Los Angeles, Sage, pp. 41-63.

Stephens, J.P. and Kanov, J. (2017), "Stories as artworks: giving form to felt dignity in connections at work", Journal of Business Ethics, Vol. 144, No. 2, pp. 235-249.

Stevenson, S.A. (2016), “Toward a narrative ethics: indigenous community-based research, the ethics of narrative, and the limits of conventional bioethics", Qualitative Inquiry, Vol. 22 No. 5, pp. 365-376.

Thiel, E.C., Bagdasarov, Z., Harkrider, L., Jonhson, J.F. and Mumford, M.D. (2012), "Leader ethical decision-making in organizations: strategies for sensemaking", Journal of Business Ethics, Vol. 107 No. 1, pp. 49-64.

Toffler, B.L. (1986), Tough choices: managers talk ethics, New York, Wiley.

Treviño, L.K, Brown, M. and Hartman, L.P. (2003), "A qualitative investigation of perceived executive ethical leadership: perceptions from inside and outside the executive suite", Human Relations, Vol. 56 No. 1, pp. 5-37.

Velasquez, M.G. (2012), Business ethics: concepts and cases, $7^{\text {th }}$ ed. Upper Saddle-River: Pearson Prentice-Hall.

White, H. (1987), The content and the form. Narrative discourse and historical representation, London, The Johns Hopkins University Press.

Wrong, D. (2004), Power. Its forms, bases and uses, London, Basil Blackwell.

Zydziunaite, V., Lepaite, D., Åstedt-Kurki, P. and Suominen, T. (2015), “Head nurses' decisionmaking when managing ethical dilemmas", Baltic Journal of Management, Vol. 10 No. 2, pp. 166-18.

Yukl, G.A. (2010). Leadership in organizations. Upper Saddle River NJ, Prentice-Hall. 
Table 1. An example of a manipulative story and its category (humorous) (Auvinen et al., 2013).

\begin{tabular}{|c|c|c|c|c|c|}
\hline $\begin{array}{c}1 . \\
\text { Example } \\
\text { story }\end{array}$ & $\begin{array}{c}2 . \\
\text { Category }\end{array}$ & $\begin{array}{c}3 . \\
\text { Context information }\end{array}$ & $\begin{array}{c}4 . \\
\text { Script }\end{array}$ & $\begin{array}{c}5 . \\
\text { Form of } \\
\text { manipulation }\end{array}$ & $\begin{array}{c}6 . \\
\text { Ethical } \\
\text { facet }\end{array}$ \\
\hline $\begin{array}{c}\text { A Hanged } \\
\text { Chef in a } \\
\text { Hotel }\end{array}$ & Humorous & $\begin{array}{l}\text { CEO in a large consulting } \\
\text { firm getting tired of the } \\
\text { "constant moaning" about } \\
\text { circumstances. She tells a } \\
\text { story (containing black } \\
\text { humor) to make the } \\
\text { consultants feel guilty. }\end{array}$ & $\begin{array}{l}\text { "A senior consultant } \\
\text { was staying in a hotel } \\
\text { in Africa in the 1970's. } \\
\text { One morning, there } \\
\text { was no breakfast in the } \\
\text { hotel - because the chef } \\
\text { had been hanged." }\end{array}$ & Dis-information & Consequence \\
\hline
\end{tabular}

Table 2. An example of a storyline of spousal support and its elements (Heikkinen et al., 2014).

\begin{tabular}{|c|c|c|c|}
\hline $\begin{array}{c}1 . \\
\text { Name of group of } \\
\text { narratives }\end{array}$ & $\begin{array}{c}2 . \\
\text { Content of the narrative }\end{array}$ & $\begin{array}{c}3 . \\
\text { Storyline of the } \\
\text { narrative }\end{array}$ & $\begin{array}{l}4 . \\
\text { The description of the } \\
\text { spousal support and its } \\
\text { evolution and connection } \\
\text { to constructed } \\
\text { gender relations }\end{array}$ \\
\hline $\begin{array}{l}\text { Harmoniously flourishing } \\
\text { spousal support }\end{array}$ & $\begin{array}{l}\text { Spousal support is narrated } \\
\text { as developing in line with } \\
\text { the woman's career from } \\
\text { practical to hands-on to } \\
\text { psychosocial support. }\end{array}$ & 'Happily-ever-after' & $\begin{array}{l}\text { Spousal support is } \\
\text { experienced as flourishing } \\
\text { and the gender relations } \\
\text { between the spouses are } \\
\text { constructed } \\
\text { cooperative, following the } \\
\text { equal gender order pattern. }\end{array}$ \\
\hline
\end{tabular}

Table 3. Summary of the two research examples (Auvinen et al., 2013; Heikkinen et al., 2014).

Example 1. Ethics and manipulation in leadership $\quad$ Example 2. Spousal support for the careers of women 


\begin{tabular}{|c|c|}
\hline storytelling & $\begin{array}{l}\text { managers and (in)equality in gender relations between } \\
\text { the spouses }\end{array}$ \\
\hline \multicolumn{2}{|l|}{ Characteristics of the narratives } \\
\hline $\begin{array}{l}\text { Short narrated accounts of manipulation in a coherent } \\
\text { or fragmented form. Each narrative gives a vantage } \\
\text { point to investigate what kind of rather short, event- } \\
\text { based stories the interviewee constructs of the topic. }\end{array}$ & $\begin{array}{l}\text { A relatively coherent account which captures and } \\
\text { covers an interviewee's story of her career and its } \\
\text { phases. Each narrative gives a vantage point to } \\
\text { investigate how the interviewee experiences and } \\
\text { understands her career as a process over the course of } \\
\text { her life and in the larger context of her life. }\end{array}$ \\
\hline \multicolumn{2}{|l|}{ Data production } \\
\hline $\begin{array}{l}\text { Open-ended interviews following broad themes: From } \\
\text { the interviews with } 9 \text { managers, } 13 \text { manipulative } \\
\text { stories were identified. }\end{array}$ & $\begin{array}{l}\text { Open-ended interviews following a rather loose semi- } \\
\text { structured guide to cover the successive phases of the } \\
\text { careers and family life of the } 25 \text { interviewees up to the } \\
\text { present. }\end{array}$ \\
\hline \multicolumn{2}{|l|}{ Analysis method } \\
\hline $\begin{array}{l}\text { In the analysis of the narrative the focus was on the } \\
\text { content of the story, and thematic analysis (Riesman, } \\
2008 \text { ) was conducted: classification of the stories } \\
\text { based on the common themes of the stories ("what is } \\
\text { said about manipulation") }\end{array}$ & $\begin{array}{l}\text { In the narrative analysis a dual-phase analysis was } \\
\text { applied: (1) content analysis was carried out to } \\
\text { interpret the different forms of spousal support ("what } \\
\text { is said about spousal support"); (2) based on the } \\
\text { narrative analysis framework of Gergen \& Gergen } \\
\text { (1988), the storylines of the interviewees' narration of } \\
\text { the evaluative shifts in the spousal support they did or } \\
\text { did not receive throughout their career were analyzed } \\
\text { ("how career and spousal support are constructed as a } \\
\text { chronological process") }\end{array}$ \\
\hline \multicolumn{2}{|l|}{ Outcome } \\
\hline $\begin{array}{l}\text { The data (13 stories) were categorized into four } \\
\text { themes of manipulation in leadership storytelling: } \\
\text { humorous, pseudo-participative, seductive, and } \\
\text { pseudo-empathetic }\end{array}$ & $\begin{array}{l}\text { The data ( } 25 \text { women managers's interviews) were } \\
\text { analyzed into four different groups of narratives based } \\
\text { on the storyline and the evolution of spousal support: } \\
\text { tragedy, 'happily-ever-after', stable, and romance }\end{array}$ \\
\hline
\end{tabular}

